\title{
Toxemia da gestação em ovelhas
}

Angela Maria Reck, Egon Henrique Horst, Kadigia Pegoraro, Letícia Misturini Dalla Costa, Marcelle Mareze

Universidade Estadual do Centro Oeste, Campus CEDETEG, Departamento de Medicina Veterinária. Guarapuava, Paraná. [marcelle_mareze@hotmail.com].

ISSUE DOI: $10.3738 / 1982.2278 .1145$

A intensificação dos sistemas brasileiros de produção de ovinos tem exigido intenso investimento no manejo nutricional dos rebanhos, tais medidas têm desencadeado enfermidades decorrentes da administração ou formulação inadequada de rações. Uma destas enfermidades é conhecida como toxemia da gestação, a literatura reconhece esta enfermidade como um quadro de cetose, desencadeado em fêmeas ovinas com gestação gemelar na maior parte dos casos, frequentemente quando estas apresentam escore corporal elevado. Tal evento se desenvolve normalmente no terço final da gestação, período no qual ocorre maior exigência energética fetal e materna, pois é nesta fase que ocorre o maior desenvolvimento do feto e ainda a fêmea necessita de energia para manutenção e produção de colostro, ocorrendo uma intensa mobilização das reservas corporais e elevando os níveis séricos de corpos cetônicos. Estes eventos estão ainda associados a menor ingestão de alimento devido à compressão do rumem pelo útero gravídico, o que agrava ainda mais o severo balanço energético negativo instalado no organismo da fêmea. Tendo em vista o grande impacto econômico ocasionado pela presença de tal distúrbio nos rebanhos, visto que a taxa de mortalidade quando não se realiza tratamento médico aproxima-se de 100\%, o diagnóstico precoce (baseado no histórico, sinais clínicos e exames laboratoriais precisos) e o tratamento imediato são de fundamental importância para evitar estas perdas econômicas. No entanto ações preventivas, visando preservar o escore corporal adequado ao parto, um manejo nutricional efetivo e redução nos fatores estressantes pré-parto, são as alternativas mais eficazes para reduzir a incidência da toxemia da prenhez no rebanho e elevar a viabilidade do sistema produtivo.

Palavras-chave: balanço energético negativo, cetose, prenhez, pré-parto, ovinos. 